\title{
OPTIMIZATION OF THE MEDIUM FOR LACTOBACILLUS ACIDOPHILUS BY PLACKETT-BURMAN AND STEEPEST ASCENT EXPERIMENT*
}

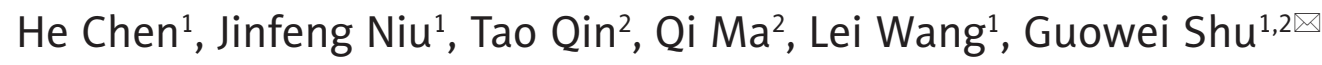 \\ ${ }^{1}$ College of Life Science and Engineering, Shaanxi University of Science and Technology \\ 710021 Xi'an, China \\ ${ }^{2}$ Enzyme Engineering Institute, Shaanxi Academy of Sciences \\ Xi'an, China
}

\begin{abstract}
Background. Lactobacillus acidophilus not only improves the intestinal flora balance but also inhabits the growth of undesirable microorganisms in intestine, which is benefit to the health of humans and animals. Plackett-Burman and steepest ascent experiment are the rapid and concise ways of screening the main effective factors. This study is aimed to select the main influence factors and optimize the medium for Lactobacillus acidophilus by Plackett-Burman experiment and steepest ascent experiment.

Material and methods. The ideal carbon source was screened among glucose, maltose, lactose and whey powder, and the ideal nitrogen source was screened among casein hydrolysate, peptone, yeast extract powder, fish meal, carbamide, ammonium sulfate and sodium nitrate by single factor experiment. Plackett-Burman and steepest ascent experiment were applied to screen the main effective factors of Lactobacillus acidophilus among peptone, beef extract, yeast extract powder, glucose, $\mathrm{K}_{2} \mathrm{HPO}_{4}, \mathrm{C}_{6} \mathrm{H}_{14} \mathrm{O}_{7} \mathrm{~N}_{2}, \mathrm{CH}_{3} \mathrm{COONa}, \mathrm{MgSO}_{4}$ and Tween-80. Result. The results indicated that glucose $(p=0.01510)$ as negative factor and $\mathrm{K}_{2} \mathrm{HPO}_{4}(p=0.02017)$ as positive effect were the significant growth factors of Lactobacillus acidophilus, $\mathrm{CH}_{3} \mathrm{COONa}(p=0.09273)$ as positive effect was an important factor, and the optimized medium was as follows: glucose $-21 \mathrm{~g} / \mathrm{L}, \mathrm{K}_{2} \mathrm{HPO}_{4}-3.5 \mathrm{~g} / \mathrm{L}$, $\mathrm{CH}_{3} \mathrm{COONa}-6.5 \mathrm{~g} / \mathrm{L}$, peptone $-10 \mathrm{~g} / \mathrm{L}$, beef extract $-8 \mathrm{~g} / \mathrm{L}$, yeast extract powder $-8 \mathrm{~g} / \mathrm{L}, \mathrm{C}_{6} \mathrm{H}_{14} \mathrm{O}_{7} \mathrm{~N}_{2}-2 \mathrm{~g} / \mathrm{L}$, $\mathrm{MgSO}_{4}-0.2 \mathrm{~g} / \mathrm{L}$ and Tween $-80-1 \mathrm{~mL} / \mathrm{L}$ when the maximum viable count could achieve $2.72 \cdot 10^{9} \mathrm{cfu} / \mathrm{mL}$.

Discussion. The experimental model is reliable and the experimental results are of good stability. Variance analysis is performed to determine the adequacy and significance of the linear model. Thus, Plackett-Burman and steepest ascent experiment improve the veracity of optimization the medium for Lactobacillus acidophilus compared with the previous research.
\end{abstract}

Key words: Lactobacillus acidophilus, Plackett-Burman experiment, steepest ascent experiment, optimization

\section{INTRODUCTION}

In recent years, with the awareness of the therapeutic effect on human health of consuming probiotic bacteria increasing (Gomes and Malcata, 1999), Lactobacillus acidophilus is a species of probiotic bacteria widely used as health foods and fermented milk (Fung et al., 2008). Dairy starter cultures (Surono and Hosono, 2002) are

\footnotetext{
*The study was partly supported by the science and technology project of Xi'an city [no. CX12186 (5)] and the key project of Shaanxi Academy of Sciences (no. 2010K-03), China.
} 
He Chen, H., Niu, J., Qin, T., Ma, Q., Wang, L., Shu, G. (2015). Optimization of the medium for Lactobacillus acidophilus by Plackett-Burman and steepest ascent experiment. Acta Sci. Pol. Technol. Aliment., 14(3), 227-232. DOI: 10.17306/J.AFS.2015.3.24

of industrial importance for fermented foods. As a major component of dairy starters Lactobacillus acidophilus has a "Generally Recognized as Safe (GRAS)" status in the USA and a "Qualified Presumption of Safety (QPS)" status in the European Union. Therefore, it is necessary to screen main influence factors of the medium in order to obtain an excellent starter with high viable counts.

The Plackett-Burman statistical method offers a design where variables are studied in $n+1$ experimental runs. This experimental design is an excellent screening method, because the required numbers of experimental runs are very few, leading to saving of time, chemicals, glassware and manpower (Carvalho et al., 1997; Srinivas et al., 1994). Moreover, the design is orthogonal in nature, implying that the effect of each variable worked out is pure in nature and not confounded with interaction among variables.

Response surface methodology (RSM) is a popular statistical method (Neelesh et al., 2014a) which contains a variety of statistical and mathematical techniques. This method is used by modelling and analysing the relationships between several independent variables and response variable(s) (Martins et al., 2013; Neelesh et al., 2014b; Piyushkumar et al., 2007). Thus, it has been widely used.

As far as can be ascertained, the present literature mainly contains the application of Plackett-Burman design and the optimization of fermentation medium (Zhang et al., 2013). The aim of the study was to screen the optimum medium for Lactobacillus acidophilus by Plackett-Burman and steepest ascent experiment. The optimized medium will improve the number of viable cells in MRS broth and prolong the growth cycle effectively, which provides the technical foundation for further producing probiotic bacteria powder.

\section{MATERIAL AND METHOD}

\section{Materials}

Glucose as the optimum carbon source was purchased from Tianjin FuChen chemical reagents factory (Tianjin, China). Both peptone and beef extract as the optimum nitrogen source came from BeiJing AoBoxing bio-tech Co. Ltd. $\mathrm{K}_{2} \mathrm{HPO}_{4}$ selected as the significant growth factor and purchased from Tianjin TianDa chemical reagents factory. $\mathrm{CH}_{3} \mathrm{COONa}$ as an important factor was from Tianjin HongYan chemical reagent factory (Tianjin, China).

\section{Bacterial strains}

The probiotic lactic acid bacteria strain, namely Lactobacillus acidophilus (Chen et al., 2012) was obtained from College of Life Science and Engineering, Shaanxi University of Science and Technology, Xi'an. MRS agar medium was selected as colony counting culture medium, which was purchased from Qingdao Hope Biol-Technology Co. Ltd. (Qingdao, China).

Activation of bacteria and cultural methods. Inoculate Lactobacillus acidophilus in MRS broth (Hopebio, Qingdao, China) at $37^{\circ} \mathrm{C}$ for $24 \mathrm{~h}$. The methods were used the methods of the toluidine blue staining and the microscopic examination to ensure no other harmful bacteria. Activate bacterial strains three successive times in anaerobic condition. MRS broth was sterilized at $115^{\circ} \mathrm{C}$ for $20 \mathrm{~min}(\mathrm{pH} 6.2-6.4)$.

Determination of viable bacterial counts and $\mathrm{pH}$ evaluation. The activated bacterial strains with $0.9 \%$ $\mathrm{NaCl}$ were diluted to suitable concentration. $1 \mathrm{~mL}$ of the appropriate dilutability into MRS agar medium was taken, and cultured at $37^{\circ} \mathrm{C}$ for $48 \mathrm{~h}$. The number of colony between 30 and 300 was selected, and then the viable count per milliliter (cfu/mL) was calculated.

The $\mathrm{pH}$ of the culture was evaluated by a $\mathrm{pH}-$ meter (pHS-3C, Shanghai Precision Scientific Instrument Co., Ltd, Shanghai, China).

\section{RESULTS AND DISCUSSION}

\section{The effect of carbon sources on the growth for Lactobacillus acidophilus}

The effect of carbon sources on the growth of Lactobacillus acidophilus is showed in Figure 1.

From Figure 1, we could find that the effect of different carbon sources on growth of Lactobacillus acidophilus had significant difference $(p<0.05)$. Whey powder and glucose were used better for Lactobacillus acidophilus, and whey powder had the best effect, less acid production and the number of colonies could rise to $1.8 \cdot 10^{9} \mathrm{cfu} / \mathrm{mL}$.

It could be drawn from the above-mentioned analysis that whey powder was the ideal carbon source for 
He Chen, H., Niu, J., Qin, T., Ma, Q., Wang, L., Shu, G. (2015). Optimization of the medium for Lactobacillus acidophilus by Plackett-Burman and steepest ascent experiment. Acta Sci. Pol. Technol. Aliment., 14(3), 227-232. DOI: 10.17306/J.AFS.2015.3.24

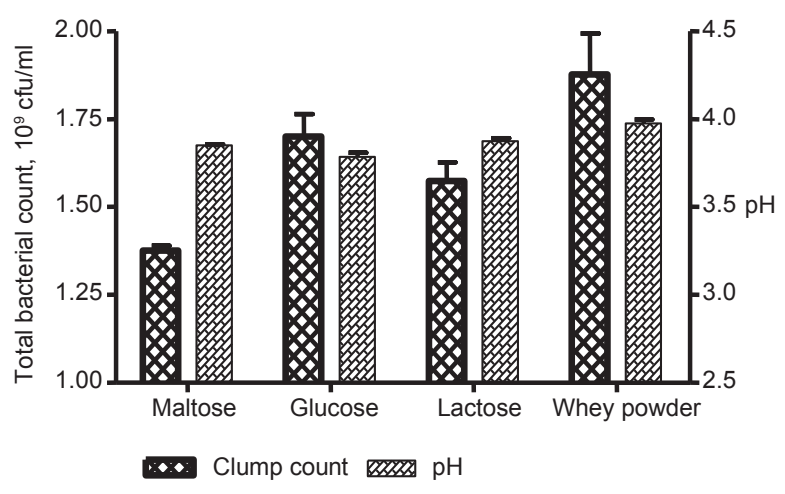

Fig. 1. Effect of carbon source on the growth of Lactobacillus acidophilus

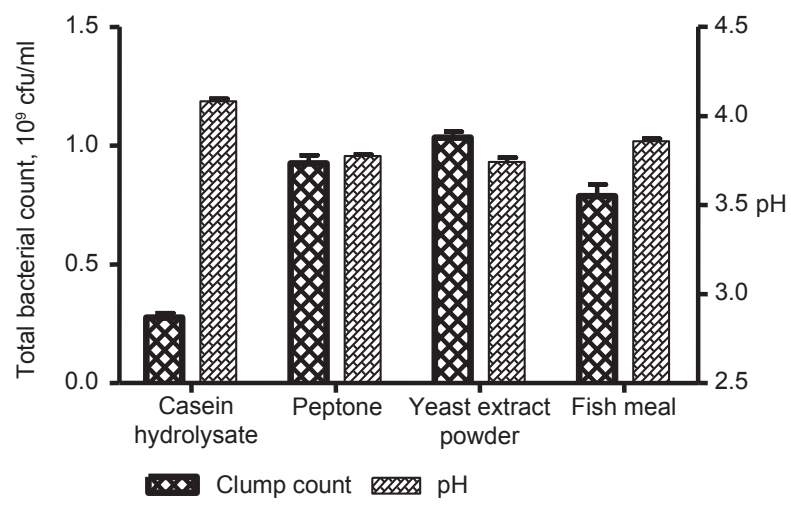

Fig. 2. Effect of organic nitrogen on the growth of Lactobacillus acidophilus

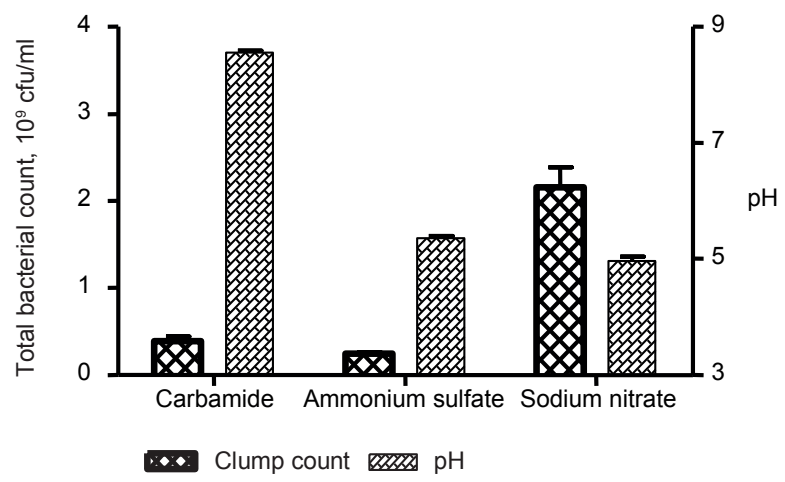

Fig. 3. Effect of inorganic nitrogen on the growth of Lactobacillus acidophilus
Lactobacillus acidophilus, but it easily to produced precipitation and would be inconvenient for subsequent preparation of bacterial powder, so glucose was used as the carbon source instead.

\section{The effect of nitrogen sources on the growth for Lactobacillus acidophilus}

The effect of nitrogen sources on the growth of Lactobacillus acidophilus and the $\mathrm{pH}$ value of culture medium were studied. The results are shown in Figure 2 and 3 .

Figure 2 and 3 respectively show that the differences of different nitrogen sources were significant $(p<0.001)$ on the growth and acid content metabolized. Organic nitrogen source could promote better growth of Lactobacillus acidophilus than inorganic nitrogen source, because it contained protein, free amino acid, peptides, glucide, fat and growth factor. Yeast extract and peptone were ideal nitrogen source of Lactobacillus acidophilus, it could be found that complex nitrogen source had better effect than single nitrogen source when compared with the basic medi$\mathrm{um}$, and that the colony number of single yeast extract was $1.1 \cdot 10^{9} \mathrm{cfu} / \mathrm{mL}$, while the colony number of the complex nitrogen source in MRS was $1.7 \cdot 10^{9} \mathrm{cfu} / \mathrm{mL}$.

It could be drawn from the above-mentioned analysis that single nitrogen source had not better effect than complex nitrogen source, so the compound of yeast extract and peptone were used as complex nitrogen source.

\section{Screening of significant growth factors of medium for Lactobacillus acidophilus}

Considering the ideal carbon source, nitrogen source and the culture medium compositions of MRS broth from Figure 3, nine kinds of factors were studied. The factors levels coding is shown in Table 1.

The design and results of tests are shown in Table 2. The response value $Y$ represented viable count in the liquid fermentation, and the unit was $10^{9} \mathrm{cfu} / \mathrm{mL}$.

Analysis of variance was shown in Table 3 in which the effect of each factor on the growth of Lactobacillus acidophilus: glucose $\left(\mathrm{X}_{4}\right)>\mathrm{K}_{2} \mathrm{HPO}_{4}\left(\mathrm{X}_{5}\right)>$ $\mathrm{CH}_{3} \mathrm{COONa}\left(\mathrm{X}_{7}\right)>$ yeast extract $\left(\mathrm{X}_{3}\right)=\mathrm{MgSO}_{4}\left(\mathrm{X}_{8}\right)>$ peptone $\left(\mathrm{X}_{1}\right)>$ beef extract $\left(\mathrm{X}_{2}\right)=\mathrm{C}_{6} \mathrm{H}_{14} \mathrm{O}_{7} \mathrm{~N}_{2}\left(\mathrm{X}_{6}\right)=$ Tween-80 $\left(\mathrm{X}_{9}\right)$. The factor whose reliability was more than $95 \%(0.01<p<0.05)$ was defined as a remarkable factor and the factor whose reliability was more 
He Chen, H., Niu, J., Qin, T., Ma, Q., Wang, L., Shu, G. (2015). Optimization of the medium for Lactobacillus acidophilus by Plackett-Burman and steepest ascent experiment. Acta Sci. Pol. Technol. Aliment., 14(3), 227-232. DOI: 10.17306/J.AFS.2015.3.24

Table 1. Factors levels coding table of Plackett-Burman

\begin{tabular}{clcc}
\hline Variables & \multicolumn{1}{c}{ Factors } & $\begin{array}{c}\text { Lower level } \\
\mathrm{g} / \mathrm{L}\end{array}$ & $\begin{array}{c}\text { Higher level } \\
\mathrm{g} / \mathrm{L}\end{array}$ \\
\hline $\mathrm{X}_{1}$ & peptone & 10 & 15 \\
$\mathrm{X}_{2}$ & beef extract & 8 & 12 \\
$\mathrm{X}_{3}$ & yeast extract powder & 4 & 6 \\
$\mathrm{X}_{4}$ & glucose & 20 & 30 \\
$\mathrm{X}_{5}$ & $\mathrm{~K}_{2} \mathrm{HPO}_{4}$ & 2 & 3 \\
$\mathrm{X}_{6}$ & $\mathrm{C}_{6} \mathrm{H}_{14} \mathrm{O}_{7} \mathrm{~N}_{2}$ & 2 & 3 \\
$\mathrm{X}_{7}$ & $\mathrm{CH}_{3} \mathrm{COONa}$ & 5 & 7.5 \\
$\mathrm{X}_{8}$ & $\mathrm{MgSO}_{4}$ & 0.2 & 0.3 \\
$\mathrm{X}_{9}$ & $\mathrm{Tween} 80$ & 1 & 1.5 \\
\hline
\end{tabular}

Table 2. Experimental design and results of Plackett-Burman

\begin{tabular}{rrrrrrrrrrr}
\hline RUN & $\mathrm{X}_{1}$ & $\mathrm{X}_{2}$ & $\mathrm{X}_{3}$ & $\mathrm{X}_{4}$ & $\mathrm{X}_{5}$ & $\mathrm{X}_{6}$ & $\mathrm{X}_{7}$ & $\mathrm{X}_{8}$ & $\mathrm{X}_{9}$ & $\begin{array}{c}\mathrm{Y}, 10^{9} \\
\mathrm{cfu} / \mathrm{mL}\end{array}$ \\
\hline 1 & 1 & -1 & 1 & -1 & -1 & -1 & 1 & 1 & 1 & 1.75 \\
2 & 1 & 1 & -1 & 1 & -1 & -1 & -1 & 1 & 1 & 1.66 \\
3 & -1 & 1 & 1 & -1 & 1 & -1 & -1 & -1 & 1 & 1.79 \\
4 & 1 & -1 & 1 & 1 & -1 & 1 & -1 & -1 & -1 & 1.69 \\
5 & 1 & 1 & -1 & 1 & 1 & -1 & 1 & -1 & -1 & 1.74 \\
6 & 1 & 1 & 1 & -1 & 1 & 1 & -1 & 1 & -1 & 1.76 \\
7 & -1 & 1 & 1 & 1 & -1 & 1 & 1 & -1 & 1 & 1.71 \\
8 & -1 & -1 & 1 & 1 & 1 & -1 & 1 & 1 & -1 & 1.74 \\
9 & -1 & -1 & -1 & 1 & 1 & 1 & -1 & 1 & 1 & 1.72 \\
10 & 1 & -1 & -1 & -1 & 1 & 1 & 1 & -1 & 1 & 1.78 \\
11 & -1 & 1 & -1 & -1 & -1 & 1 & 1 & 1 & -1 & 1.74 \\
12 & -1 & -1 & -1 & -1 & -1 & -1 & -1 & -1 & -1 & 1.73 \\
\hline
\end{tabular}

Table 3. ANOVA of Plackett-Burman

\begin{tabular}{ccccccc}
\hline Source & df & $S S$ & $M S$ & $F$ & $p$ & Significance \\
\hline $\mathrm{X}_{1}$ & 1 & 0.000208 & 0.000208 & 1.923077 & 0.29986 & \\
$\mathrm{X}_{2}$ & 1 & $8.33 \mathrm{E}-06$ & $8.33 \mathrm{E}-06$ & 0.076923 & 0.80755 & \\
$\mathrm{X}_{3}$ & 1 & 0.000408 & 0.000408 & 3.769231 & 0.19171 & \\
$\mathrm{X}_{4}$ & 1 & 0.007008 & 0.007008 & 64.69231 & 0.015108 & $*$ \\
$\mathrm{X}_{5}$ & 1 & 0.005208 & 0.005208 & 48.07692 & 0.020173 & $*$ \\
$\mathrm{X}_{6}$ & 1 & $8.33 \mathrm{E}-06$ & $8.33 \mathrm{E}-06$ & 0.076923 & 0.80755 & \\
$\mathrm{X}_{7}$ & 1 & 0.001008 & 0.001008 & 9.307692 & 0.092735 & \\
$\mathrm{X}_{8}$ & 1 & 0.000408 & 0.000408 & 3.769231 & 0.19171 & \\
$\mathrm{X}_{9}$ & 1 & $8.33 \mathrm{E}-06$ & $8.33 \mathrm{E}-06$ & 0.076923 & 0.80755 & \\
\hline
\end{tabular}

$* * * p<0.0001-$ highly significant, $* * p<0.001$ - very significant, $* p<0.05$ - significant.

than $90 \%(0.05<p<0.1)$ was important factor in general statistics.

It was shown that glucose $\left(\mathrm{X}_{4}\right)$ and $\mathrm{K}_{2} \mathrm{HPO}_{4}\left(\mathrm{X}_{5}\right)$ were remarkable factors, and $\mathrm{CH}_{3} \mathrm{COONa}\left(\mathrm{X}_{7}\right)$ was important factor on growth of Lactobacillus acidophilus in Table 3. Similarly, from Figure 4, we could find that the factors of $X_{4}, X_{5}$ and $X_{7}$ had greater effect on the growth of Lactobacillus acidophilus, it also indicated positive or negative effects and the influence intensity of each factor on the response values.

We screened two significant factors of glucose $\left(\mathrm{X}_{4}\right)$, $\mathrm{K}_{2} \mathrm{HPO}_{4}\left(\mathrm{X}_{5}\right)$ and one important factor of $\mathrm{CH}_{3} \mathrm{COONa}$ $\left(\mathrm{X}_{7}\right)$ by the Plackett-Burman experiment design and then did further research and analysis. The other factors were determined as: the $X_{1}$ to -1 level, $X_{2}$ to -1 level, $X_{3}$ to 1 level, $X_{6}$ to -1 level, $X_{8}$ to -1 level and $X_{9}$ to 


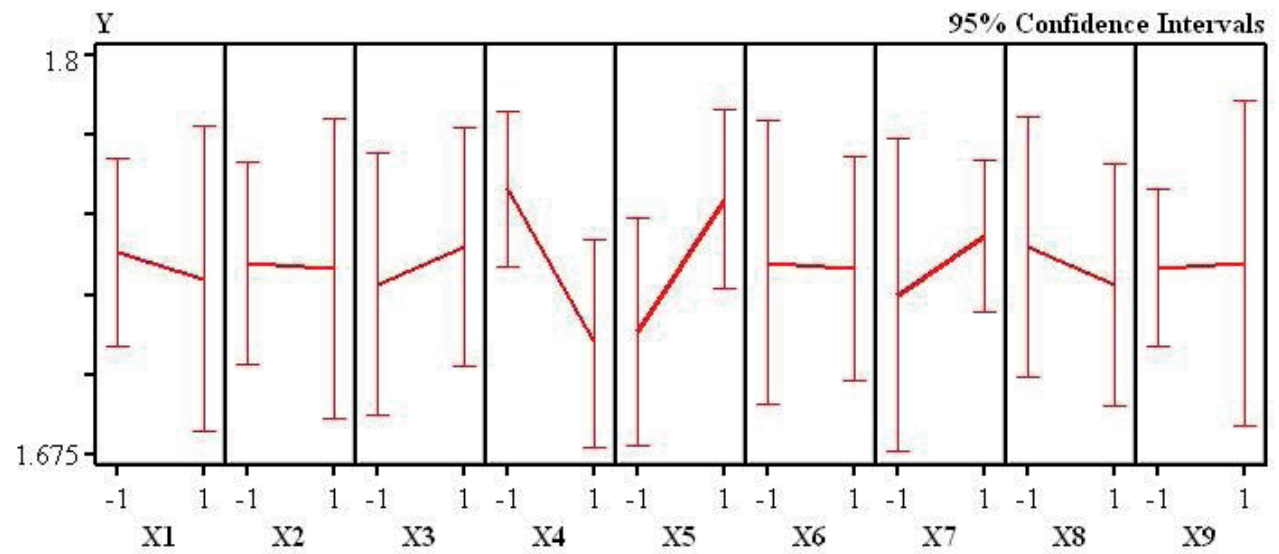

Fig. 4. 95\% confidence interval of growth factors

Table 4. Design and results of the path of steepest ascent experiment

\begin{tabular}{cclcc}
\hline $\begin{array}{c}\text { Number } \\
\text { of steps }\end{array}$ & $\mathrm{X}_{4}$ & $\mathrm{X}_{5}$ & $\mathrm{X}_{7}$ & $\begin{array}{c}\text { Number of colony } \\
10^{9} \mathrm{cfu} / \mathrm{mL}\end{array}$ \\
\hline 1 & 30 & 2 & 5 & 1.67 \\
2 & 27 & 2.5 & 5.5 & 1.86 \\
3 & 24 & 3 & 6 & 2.41 \\
4 & 21 & 3.5 & 6.5 & 2.72 \\
5 & 18 & 4 & 7 & 1.45 \\
\hline
\end{tabular}

-1 level, namely, peptone $10 \mathrm{~g} / \mathrm{L}$, beef extract $8 \mathrm{~g} / \mathrm{L}$, yeast extract powder $8 \mathrm{~g} / \mathrm{L}$, citric acid hydrogen ammonia $2 \mathrm{~g} / \mathrm{L}$, magnesium sulfate $0.2 \mathrm{~g} / \mathrm{L}$ and Tween-80 $1 \mathrm{ml} / \mathrm{L}$ according to Figure 4.

The results analysis of steepest ascent experiment The results were as shown in Table 4 which showed that optimum value area was located in step 4. Glucose $\left(\mathrm{X}_{4}\right)$ as the negative effect should be reduced; $\mathrm{K}_{2} \mathrm{HPO}_{4}\left(\mathrm{X}_{5}\right)$ and $\mathrm{CH}_{3} \mathrm{COONa}\left(\mathrm{X}_{7}\right)$ as positive effect should be increased. According to the effect of three factors, changed direction and a set of experimental runs were designed.

\section{CONCLUSIONS}

This study result showed that glucose $\left(\mathrm{X}_{4}\right)$ and $\mathrm{K}_{2} \mathrm{HPO}_{4}$ $\left(\mathrm{X}_{5}\right)$ were remarkable factors, and $\mathrm{CH}_{3} \mathrm{COONa}\left(\mathrm{X}_{7}\right)$ was important factor on growth of Lactobacillus acidophilus. The viable count would increase with the $\mathrm{X}_{5}$ and $X_{7}$, and decrease with $X_{4}$. Effect of each factor on the growth of Lactobacillus acidophilus: glucose $\left(\mathrm{X}_{4}\right)>\mathrm{K}_{2} \mathrm{HPO}_{4}\left(\mathrm{X}_{5}\right)>\mathrm{CH}_{3} \mathrm{COONa}\left(\mathrm{X}_{7}\right)>$ yeast extract $\left(\mathrm{X}_{3}\right)=\mathrm{MgSO}_{4}\left(\mathrm{X}_{8}\right)>$ peptone $\left(\mathrm{X}_{1}\right)>$ beef ex$\operatorname{tract}\left(\mathrm{X}_{2}\right)=\mathrm{C}_{6} \mathrm{H}_{14} \mathrm{O}_{7} \mathrm{~N}_{2}\left(\mathrm{X}_{6}\right)=$ Tween-80 $\left(\mathrm{X}_{9}\right)$. The optimized medium component was as follows: glucose $-21 \mathrm{~g} / \mathrm{L}, \mathrm{K}_{2} \mathrm{HPO}_{4}-3.5 \mathrm{~g} / \mathrm{L}, \mathrm{CH}_{3} \mathrm{COONa}-6.5 \mathrm{~g} / \mathrm{L}$, peptone $-10 \mathrm{~g} / \mathrm{L}$, beef extract $-8 \mathrm{~g} / \mathrm{L}$, yeast extract powder $-8 \mathrm{~g} / \mathrm{L}, \mathrm{C}_{6} \mathrm{H}_{14} \mathrm{O}_{7} \mathrm{~N}_{2}-2 \mathrm{~g} / \mathrm{L}, \mathrm{MgSO}_{4}-0.2 \mathrm{~g} / \mathrm{L}$ and Tween-80 - $1 \mathrm{~mL} / \mathrm{L}$ when the maximum viable count could achieve $2.72 \cdot 10^{9} \mathrm{cfu} / \mathrm{mL}$.

\section{REFERENCES}

Ariga, O., Toyofuku, H., Minegishi, I., Hattori, T., Sano, Y., Nagura, M. (1997). Efficient production of recombinant enzymes using PVA encapsulated bacteria. J. Ferm. Bioeng., 84, 553-557.

Bai, J. L., Mo, S. P., Zheng, W. L. (2007). Lactic acid bacteria enrichment medium nutrition factor optimization industry. J. Food Ferm. Ind., 33(2), 79-81.

Bukharin, O. V., Sgibnev, A. V. (2013). Effect of metabolites of $\mathrm{H}_{2} \mathrm{O}_{2}$-producing lactobacilli on functional activity of lysozyme. Zhur. Mikrob. Epidem. Iimmunobiol., 4, 60-64.

Carvalho, C. M. L., Serralheiro, M. L. M., Cabral, J. M. S., Airebarros, M. R. (1997). Application of factorial design to the study of transesterification reactions using cutinase in AOT-reversed micelles. Enz. Microb. Techn., 27, 117-123.

Chen, H., Li, C. N., Shu, G. W., Wang, C. F. (2012). Screening of nitrogen sources in the medium for Streptococcus 
He Chen, H., Niu, J., Qin, T., Ma, Q., Wang, L., Shu, G. (2015). Optimization of the medium for Lactobacillus acidophilus by Plackett-Burman and steepest ascent experiment. Acta Sci. Pol. Technol. Aliment., 14(3), 227-232. DOI: 10.17306/J.AFS.2015.3.24

thermophilususing Plackett-Burman design. Adv. Mat. Res., 531, 532-535.

Colombo, M., Oliveira, A. E. Z., Carvalho, A. F., Nero, L. A. (2014). Regulation of exopolysaccharide production by Lactobacillus lactic subsp. Food Microbiol., 39, 89-95.

Fung, W. Y., Woo, Y. P., Liong, M. T. (2008). Optimization of growth of Lactobacillus acidophilus FTCC 0291 and evaluation of growth characteristics in soy whey medium: a response surface methodology approach. J. Agric. Food Chem., 56, 7910-7918.

Gomes, A. M. P., Malcata, F. X. (1999). Dobacterium spp. and Lactobacillus acidophilus: Biological, biochemical, technological and therapeutical properties relevant for use as probiotics. Trends Food Sci. Tech., 10, 139-157.

Gran, H. M., Gadaga, H. T., Narvhus, J. A. (2003). Utilization of various starter cultures in the production of Amasi, a Zimbabwean naturally fermented raw milk product. Int. J. Food Microbiol., 88, 19-28.

Kirmizakis, P., Tsamoutsoglou, C., Kayan, B., Kalderis, D. (2014). Subcritical water treatment of landfill leachate: Application of response surface methodology. J. Environ. Manag., 146, 9-15.

Li, J. X., Luo, Y., Tian, P. F. (2010). Optimizing lactobacillus casei fermentation culture medium of progretive bacteriocins by the response surface method. J. Henan Univ. Techn., 31(3), 45-49.

Looijesteijn, P. J., Boels, I. C., Kleerebezem, M., Hugenholtz, J. (1999). Regulation of exopolysaccharide production by Lactobacillus lactic subsp. cremorisby the sugar source. Appl. Environ., 65, 5003-5008.

Martins, A. C., Bukman, L., Vargas, A. M. M., Barizão, É. O., Moraes, J. C. G., Visentainer J. V., Almeida, V. C. (2013). The antioxidant activity of teas measured by the FRAP method adapted to the FIA system: Optimizing the conditions using the response surface methodology. Food Chem., 138, 574-580.

Mundra, P., Desai, K., Lele, S. S. (2007). Application of response surface methodology to cell immobilization for the production of palatinose. Biores. Techn., 98, 2892-2896.

Naveena, B. J., Altaf, M., Bhadriah, K. G. (2005). Reddy Selection of medium components by Plackett-Burman design for production of $\mathrm{L}(+)$ lactic acid by Lactobacillus amylophilus GV6 in SSF using wheat bran. Biores. Techn., 96, 485-490.

Received - Przyjęto: 11.12.2014

For citation - Do cytowania
Neelesh, S., Garima, S., Mahe, T., Himanshu, R., Onkar, N. S., Arvind, M. K. (2014). Cicer $\alpha$-galactosidase immobilization onto functionalized graphene nanosheets using response surface method and its applications. Food Chem., 142, 430-438.

Singh, N., Srivastava, G., Raghubanshi, H., Srivastava, O. N., Kayastha, A. M. (2014). Cicer $\alpha$-galactosidase immobilization onto functionalized graphene nanosheets using response surface method and its applications. Food Chem., 142, 430-438.

Park, J. K., Chang, H. N. (2000). Microencapsulation of the microbial cells. Biotechn. Adv., 18, 303-319.

Piyushkumar, M., Kiran, D., Lele, S. S. (2007). Application of response surface methodology to cell immobilization for the production of palatinose. Biores. Techn., 98, 2892-2896.

Surono, I., Hosono, A. (2002). Starter cultures. Nagano-Ken, Japan: Shinsyu University.

Srinivas, M. R. S., Naginchand, Lonsane, B. K. (1994). Use of Plackett-Burman design for rapid screening of several nitrogen sources, growth/product promoters, minerals and enzyme inducers for the production of alpha-galactosidase by Aspergillus niger MRSS 234 in solid state fermentation. Bioproc. Eng., 10, 139-144.

Tian, H. T., Jia, Y. M., ..., Ma, W. (2002). Thermophilic streptococcus growth promoting substance research and proliferation medium optimization selection. J. Food Sci., 23(5), 60-62.

Wang, Y. R., Liu, D. W., Zhang, M. H. (2010). The response surface method optimization of Lactobacillus acidophilus whey medium. China Brew., 10, 77-78.

Yi, H. X., Han, X., Du, M. etc. (2010). MRS culture medium components of Lactobacillus J23 effects of antibacterial peptide Bac-J23. China Brew., 31(5), 56-58.

Zhao, R. X., Sun, J. L., Li, M. J. (2005). Lactobacillus acidophilus assimilates cholesterol capacity in MRS medium. Chin. J. Microecol., 17(4), 254-255.

Zhang, S. W., Huang, J. F., Luo, L. X. (2013). Optimization of fermentation medium for protease production by $\mathrm{Ba}$ cillus subtilis. China Brew., 251(2).

Zhuang, X. L., Zhang, H. X., Ma, G. R. (2000). The main factors that influence the milk peptide chain bacteria fermentation. Chem. Metal., 21(1), 93-97.

Zhang, Y., Leng, Y. F., Li, J. H. (2011). The response surface method optimization of Lactobacillus acidophilus proliferation medium. Chinese Brew., 134-137.

Accepted for print - Zaakceptowano do druku: 26.04.2015

He Chen, H., Niu, J., Qin, T., Ma, Q., Wang, L., Shu, G. (2015). Optimization of the medium for Lactobacillus acidophilus by Plackett-Burman and steepest ascent experiment. Acta Sci. Pol. Technol. Aliment., 14(3), 227-232. DOI: 10.17306/J.AFS.2015.3.24 